\title{
The Glycaemic Index of Foods Tested in Diabetic Patients: A New Basis for Carbohydrate Exchange Favouring the Use of Legumes
}

\author{
D.J.A.Jenkins ${ }^{1,2}$, T. M.S. Wolever ${ }^{1}$, A. L. Jenkins ${ }^{1}$, M.J. Thorne ${ }^{1}$, R. Lee ${ }^{2}$, J. Kalmusky ${ }^{1}$, R. Reichert ${ }^{1}$ and G. S. Wong ${ }^{2}$ \\ ${ }^{1}$ Department of Nutritional Sciences, Faculty of Medicine and ${ }^{2}$ St. Michael's Hospital, University of Toronto, Toronto, Canada
}

\begin{abstract}
Summary. Recently diabetic patients have been encouraged to increase their carbohydrate intake, but exact details of which foods to use are lacking. To determine whether sufficiently large differences existed to justify more specific dietary advice, we compared the glycaemic responses to $50 \mathrm{~g}$ carbohydrate portions of different foods, taken as breakfast test meals by groups of five to seven diabetic patients. Two- to threefold differences were seen amongst the 15 foods tested. The glycaemic responses for spaghetti, 'All-bran', rice and beans were significantly below those for bread, while 'Cornflakes' were above. Factors predicted to influence this were without effect, including: substituting wholemeal for white bread, increasing substantially the simple sugars (using 'All-bran' or bananas instead of wholemeal bread) and doubling meal protein by adding cottage cheese to bread. Paired comparisons of the glycaemic response to the five legumes with those of the seven
\end{abstract}

other starchy foods (breads, spaghetti, rice, Cornflakes, oatmeal porridge and potatoes) showed that the mean peak rise in blood glucose concentration and mean area under the glucose curve after beans were 23 and $28 \%$ lower, respectively, than the mean for the other foods $(p<0.001)$. Such results suggest a potentially valuable role for dried leguminous seeds in carbohydrate exchanges for individuals with impaired carbohydrate tolerance. These large differences in the blood glucose response to different food cannot at present be predicted directly from tables of chemical composition. Nevertheless, physiological testing may both aid in understanding the factors responsible and help selection of the appropriate carbohydrate foods for the diabetic diet.

Key words: Glycaemic index, leguminous seeds, low blood glucose rise, diabetes, diabetic diet, fat, sugars, protein.
To lessen the risk to the diabetic of carciovascular disease, current dietary guidelines of the American [1] and Canadian [2] Diabetes Associations and the British Diabetic Association [3] have recommended increasing complex carbohydrate and fibre intakes, while reducing fat consumption. Exactly how this should be achieved is not known and there are fears that increased intake of specific foods, or carbohydrates in general, may worsen diabetic control [4]. However, in the context of high fibre diets this does not appear to be the case [5]. Indeed studies using purified fibre and high-fibre, high-carbohydrate diets have been associated with improved diabetic control [9-15]. Nevertheless, the carbohydrate foods of greatest potential use to the diabetic have not as yet been defined and it has now been acknowledged that information on the glycaemic effect of individual foods and meals is urgently needed [3].

We have therefore compared the effect of taking $50 \mathrm{~g}$ carbohydrate portions of 15 different foods on the blood glucose responses of diabetic patients. We wished to determine whether large differences existed which favoured the use of particular foods. It was also important to see whether these differences related to specific food constituents (fibres, sugars, proteins, etc.).

\section{Methods}

Groups of five to seven highly motivated diabetic volunteers from a pool of 12 came fasting to the Diabetic Day Care Unit of St. Michael's Hospital, Toronto, weekly. There were six men and six women, aged $67 \pm 2$ years, $138 \pm 11 \%$ desirable weight [16]; ten took insulin (28 \pm $5 \mathrm{U}$ daily) and two took oral agents (Table 1 ).

The majority (subjects 1-9) were studied over a 5-month period and on average attended 15 of the 19 sessions. Three further volunteers (10-12) attended a subsequent seven or eight sessions.

Although C-peptide measurements were not available it is likely that all but one of the volunteers had Type 2 (non-insulin-dependent) diabetes, being non-ketosis-prone and predominantly overweight although requiring insulin for adequate control. The one possible Type 1 (insulin-dependent) diabetic patient (No.2) was slightly below ideal body weight, but was not ketosis prone.

At the sessions, volunteers took test meals containing $50 \mathrm{~g}$ carbohydrate portions of specific foods as estimated from food tables [17-19]. A total of 15 foods were tested (Table 2). Each individual was 
Table 1. Details of diabetic volunteers

\begin{tabular}{|c|c|c|c|c|c|c|c|c|c|}
\hline Volunteer & Sex & $\begin{array}{l}\text { Age } \\
\text { (years) }\end{array}$ & $\begin{array}{l}\text { Number } \\
\text { of tests }\end{array}$ & $\begin{array}{l}\text { Height } \\
(\mathrm{cm})\end{array}$ & $\begin{array}{l}\text { Mean weight } \\
(\mathrm{kg})\end{array}$ & $\begin{array}{l}\% \text { Ideal } \\
\text { weight }\end{array}$ & $\begin{array}{l}\text { Duration } \\
\text { of diabetes } \\
\text { (years) }\end{array}$ & $\begin{array}{l}\text { Medication } \\
\text { (units }(\mathrm{mg}) / \text { day) }\end{array}$ & $\begin{array}{l}\text { Fasting blood } \\
\text { glucose } \\
(\mathrm{mmol} / 1)\end{array}$ \\
\hline 2 & M & 70 & 19 & 184 & $71.4 \pm 0.1$ & 96 & 31 & 19 Lente, 35 soluble insulin & $4.5 \pm 0.4$ \\
\hline 3 & $F$ & 64 & 18 & 161 & $65.3 \pm 0.1$ & 123 & 25 & 22 Lente insulin & $8.7 \pm 0.3$ \\
\hline 4 & $\mathrm{~F}$ & 74 & 17 & 156 & $76.3 \pm 0.2$ & 151 & 11 & 28 Lente insulin & $9.4 \pm 0.4$ \\
\hline 5 & M & 74 & 12 & 179 & $83.2 \pm 0.2$ & 118 & 3 & 22 Lente insulin & $5.7 \pm 0.1$ \\
\hline 7 & M & 76 & 13 & 164 & $74.3 \pm 0.1$ & 124 & 13 & 55 Lente insulin & $9.0 \pm 0.6$ \\
\hline 8 & M & 68 & 7 & 165 & $66.6 \pm 0.5$ & 110 & 2 & $30 / 28$ Lente insulin & $12.5 \pm 0.4$ \\
\hline 9 & M & 59 & 10 & 171 & $80.7 \pm 0.2$ & 134 & 4 & 5 Lente insulin & $7.0 \pm 0.2$ \\
\hline 10 & $\mathrm{~F}$ & 53 & 8 & 145 & $72.9 \pm 0.2$ & 165 & 17 & 15 Lente insulin & $9.3 \pm 0.4$ \\
\hline 11 & $\mathrm{~F}$ & 61 & 7 & 155 & $57.1 \pm 0.1$ & 106 & 1 & 25 Lente insulin & $5.4 \pm 0.2$ \\
\hline 12 & $\mathrm{M}$ & 74 & 7 & 161 & $70.2 \pm 0.3$ & 121 & 12 & 24 Lente, 4 soluble insulin & $9.7 \pm 0.4$ \\
\hline Mean $\pm \mathrm{SE}$ & & $67 \pm 2$ & $13 \pm 1$ & $163 \pm 3$ & $77.1 \pm 4.4$ & $138 \pm 11$ & $11 \pm 3$ & $28 \pm 5$ & $8.0 \pm 0.6$ \\
\hline
\end{tabular}

a Mean of three periods: chlorpropamide $250 \mathrm{mg}$ for seven tests (fasting blood glucose $6.4 \pm 0.2 \mathrm{mmol} / 1$ ); no medication, seven tests (fasting blood glucose $8.8 \pm 0.5 \mathrm{mmol} / \mathrm{l}$ ) ${ }^{b}{ }^{b}$ glibenclamide (glyburide (USP)) $10 \mathrm{mg}$, two tests (fasting blood glucose $6.5 \pm 0.0 \mathrm{mmol} / 1$ )

Table 2. Meal constituents of foods tested

\begin{tabular}{|c|c|c|c|c|c|c|c|c|}
\hline \multirow[t]{2}{*}{ Meal } & \multicolumn{8}{|c|}{ Meal constituents } \\
\hline & $\begin{array}{l}\text { Dry } \\
\text { weight } \\
\text { (g) }\end{array}$ & $\begin{array}{l}\text { Cooked } \\
\text { weight } \\
\text { (g) }\end{array}$ & $\begin{array}{l}\text { Protein } \\
\text { (g) }\end{array}$ & $\begin{array}{l}\text { Fat } \\
\text { (g) }\end{array}$ & $\begin{array}{l}\text { Carbo- } \\
\text { hydrate } \\
(\mathrm{g})\end{array}$ & $\begin{array}{l}\text { Sugars } \\
\text { (g) }\end{array}$ & $\begin{array}{l}\text { Dietary } \\
\text { fibre } \\
\text { (g) }\end{array}$ & $\begin{array}{l}\text { Energy } \\
\text { (kcal) }\end{array}$ \\
\hline Wholemeal bread & $76^{a}$ & 121 & 10.0 & 1.5 & 50.0 & 1.8 & 7.3 & 164 \\
\hline $\begin{array}{l}\text { Wholemeal bread } \\
\text { and cottage cheese }\end{array}$ & $\begin{array}{l}76^{\mathrm{a}} \\
89\end{array}$ & 210 & 22.1 & 3.5 & 51.2 & 3.0 & 7.3 & 249 \\
\hline $\begin{array}{l}\text { Wholemeal bread } \\
\text { and milk }\end{array}$ & $\begin{array}{r}76^{\mathrm{a}} \\
250\end{array}$ & 371 & 19.9 & 6.9 & 62.9 & 14.7 & 7.3 & 326 \\
\hline White bread & $66.8^{\mathrm{a}}$ & 170 & 7.6 & 0.8 & 50.0 & 1.0 & 2.0 & 156 \\
\hline $\begin{array}{l}1 / 2 \text { Wholemeal bread } \\
\text { and cottage cheese }\end{array}$ & $\begin{array}{l}38^{\mathrm{a}} \\
89\end{array}$ & 150 & 17.1 & 2.8 & 26.2 & 2.1 & 3.7 & 167 \\
\hline $\begin{array}{l}\text { Wholemeal bread, } \\
\text { butter and } \\
\text { marmalade }\end{array}$ & $\begin{array}{l}57^{\mathrm{a}} \\
17.7 \\
17.9\end{array}$ & 157.1 & 7.6 & 15.6 & 50.0 & 13.8 & 5.6 & 341 \\
\hline White rice & 58 & 256 & 3.8 & 0.6 & 50.3 & Trace & 1.4 & 209 \\
\hline White spaghetti & 59.5 & 146 & 8.1 & 0.6 & 50.0 & 1.6 & 2.0 & 225 \\
\hline 'All-bran'b & 116 & 116 & 17.5 & 6.6 & 49.9 & 17.9 & 31.0 & 317 \\
\hline ‘Cornflakes'b & 59 & 59 & 5.1 & 0.9 & 50.2 & 4.4 & 6.5 & 217 \\
\hline Porridge oats ${ }^{b}$ & 69 & 390 & 8.6 & 6.0 & 50.2 & Trace & 4.8 & 277 \\
\hline Digestive biscuit & 76 & 76 & 7.5 & 15.6 & 50.2 & 12.5 & 4.2 & 358 \\
\hline Banana & 260 & & 2.9 & 0.8 & 49.9 & 42.1 & 8.8 & 205 \\
\hline New potato & - & 273 & 4.4 & 0.3 & 50.0 & 12.5 & 4.2 & 207 \\
\hline Kidney beans & 111.1 & 339 & 24.6 & 1.9 & 50.0 & 3.3 & 27.8 & 315 \\
\hline Romano beans ${ }^{c}$ & 78.5 & 228.6 & 18.0 & 0.9 & 50.0 & 2.4 & 19.6 & 280 \\
\hline Red lentils & 94 & 302.4 & 22.4 & 0.9 & 50.0 & 2.3 & 11.0 & 286 \\
\hline Black eye peas & 83.3 & 264.5 & 18.3 & 1.3 & 50.0 & 3.0 & 16.0 & 283 \\
\hline Chick peas & 100 & 249.5 & 20.2 & 5.7 & 50.0 & 10.0 & 15.0 & 320 \\
\hline
\end{tabular}

${ }^{\text {a }}$ Weight of dry flour; ${ }^{b}$ nutrients not including $250 \mathrm{ml} 2 \%$ milk taken with all cereals; ${ }^{c}$ fibre content assumed to be the same as in kidney beans according to Paul and Southgate [17] other nutrients according to Platt [18]; ${ }^{\mathrm{d}}$ nutrients and fibre according to Adams [19]

asked to take at least one wholemeal bread and cottage cheese meal (containing $50 \mathrm{~g}$ of carbohydrate from bread) as a standard with which other foods were compared.

Cottage cheese was added to the wholemeal bread to provide a meal protein content equivalent to the legumes, the highest protein foods tested. Each individual used in the glycaemic index study (except patient 8 ) took the standard bread and cottage cheese meal on more than one occasion, the mean being once for every six other foods tested (range 4-9). The data on the three individuals (subjects
10-12) who were studied at a later date but were not able to be included in the glycaemic index comparison, were used in the subsequent comparison of legumes with the other starchy foods.

The breads were baked in the diet kitchen. Dry legumes were precooked in batches by boiling in a minimum of salted water, aliquoted and frozen before reheating to boiling on the morning of the test. Potatoes were boiled on the day before the test and heated in the oven before eating. Rice, spaghetti, and porridge oats were cooked on the morning of the test by boiling in a minimum of salted water. In addi- 
tion, all non-sweet meals were served with $100 \mathrm{~g}$ raw tomato. Breakfast cereals and bread and milk meals were taken with $250 \mathrm{ml} 2 \%$ butterfat milk.

The first meal was taken with either one to two cups of water, coffee or tea, with milk as determined by individual taste. This same amount and type of beverage was then taken with all subsequent test meals. In addition to the standard bread and cottage cheese meal, five other types of bread test meals were performed including: a half portion of bread with cottage cheese; wholemeal bread with $250 \mathrm{ml} 2 \%$ butterfat milk; wholemeal bread without cottage cheese; substitution of $26 \%$ of the bread carbohydrate $(12.5 \mathrm{~g})$ by the sugars in $18 \mathrm{~g}$ marmalade; and white bread containing the same amount of carbohydrate as the wholemeal bread $(50 \mathrm{~g})$. These were designed to assess the effect on glycaemic response of carbohydrate dose, milk as used on the breakfast cereals, and the protein, sugar and wheat fibre contents of the meal.

Volunteers took their insulin or oral hypoglycaemic agents 5-10 min before the meal. They were asked to eat the meal over a 10min period. Finger prick capillary blood samples were obtained before taking insulin or oral agents and then at 30-min intervals after the start of the meal for the following $3 \mathrm{~h}$. These were analysed for glucose by a glucose oxidase method $[20,21]$.

During the series of tests, patients remained on the same diet and medications with the exception of three patients: patient 2 exchanged $2 \mathrm{U}$ lente for $2 \mathrm{U}$ soluble insulin; patient 8 reduced his insulin dose from 30 to $28 \mathrm{U}$ lente insulin; and patient 1 discontinued her oral agents for the middle part of the study (Table 1). Only patient 1 showed a change in fasting blood glucose with a change in medication and a separate bread and cottage cheese meal was therefore used for comparison with the other tests performed during this period.

Peak rises are given as the difference between the highest postprandial blood glucose value minus the fasting value. Areas under the curve were calculated geometrically as the area above the fasting value. To allow direct comparison with the breakfast cereals, the blood glucose response to $250 \mathrm{ml}$ milk was deducted from the values for the cereal. This correction factor was derived from additional tests on five subjects who took both wholemeal bread alone and wholemeal bread with $250 \mathrm{ml}$ milk. The blood glucose area for each food was expressed as a percentage of the mean area of that individual's wholemeal bread and cottage cheese standard tests. The mean of these values for each food was defined as the 'glycaemic index' for that food [20]:

Area under the $3 \mathrm{~h}$ glucose response curve for a food Area under the $3 \mathrm{~h}$ glucose response curve for the $\times 100$ equivalent amount of bread.

Detailed comparisons of the blood glucose response to the five legumes were made directly with those of the other seven starchy foods. For this purpose, the results of patient 1 were excluded because of a change in diabetic therapy and three additional patients (subjects 10-12) added. These subjects had taken both cereals and legumes, but not all had eaten the bread and cottage cheese which could have enabled their inclusion in the glycaemic index data.

Results are given as mean \pm SEM. The significances were calculated using Student's t-test for paired and unpaired data. For paired data, in addition to Student's t-test, Fishers' test was also used after demonstration of significant heterogeneity with a one-way analysis of variance and the lower significance level taken. Correlation coefficients were calculated by the method of least squares.

\section{Results}

\section{Glycaemic Index}

In general, the meals were well received. In only one case was the full amount not eaten. Patient 4 ate only $50 \%$ of the chick peas which were therefore compared with the 'half bread' test meal.
Large differences were seen in the mean glycaemic responses between individual foods. The mean glycaemic index of 'Cornflakes' was three times that of lentils (Table 3). These two foods represented the upper and lower ends of the range. Values for rice, 'All-bran', spaghetti and beans were all significantly below those for bread and cheese by $20 \%(p<0.05), 28 \%(p<0.005)$, $40 \%(p<0.01)$, and 29\%-56\% $(p<0.005-0.001)$ respectively. Values for 'Cornflakes' were significantly above by $23 \%(p<0.01$; Table 3$)$.

The glycaemic index of the half $(25 \mathrm{~g})$ carbohydrate bread breakfast was $58 \%$ that of the full $(50 \mathrm{~g})$ bread test meal and so showed the expected proportionality. The glycaemic response to wholemeal bread was not significantly altered by addition of $89 \mathrm{~g}$ cottage cheese, $250 \mathrm{ml}$ milk or substitution of the sugars in $18 \mathrm{~g}$ marmalade for $26 \%$ of the starch in bread. In addition, substitution of white for wholemeal bread made no difference to the glycaemic response. Overall, there was no correlation between total fat, protein, fibre, sugar or energy content of the foods and the glycaemic index.

The mean times for eating the individual foods ranged from 8 to $15 \mathrm{~min}$, the mean for all foods being $12 \pm 1 \mathrm{~min}$. The standard bread and cottage cheese and bread and milk meals took longest $(15 \mathrm{~min})$ while spaghetti, porridge, lentils and banana were the most rapidly eaten with mean times between $8-9 \mathrm{~min}$. There was no signficant relationship between the glycaemic index and eating time $(r=0.217)$. For example, the two lowest glycaemic index foods, lentils and chick peas, represented short ( $8 \mathrm{~min}$ ) and long (13 min) eating times respectively.

Mean fasting blood glucose values were comparable for each food tested. No trend was seen during the course of the tests in body weight, fasting blood glucose level and glycaemic responses to the standard test meal. At the beginning and end of the study period, the mean values were, respectively: body weight: $81 \pm 5$ and $81 \pm 6 \mathrm{~kg}$; fasting blood glucose $8.4 \pm 1$ and $7.9 \pm$ $1 \mathrm{mmol} / 1$; and blood glucose area following the standard bread and cheese meal $777 \pm 100$ and $844 \pm$ $125 \mathrm{mmol} \cdot 1^{-1} \cdot \mathrm{min}$.

Using the data for the 123 test meals taken, there was no significant correlation between fasting blood glucose level and peak rise $(r=-0.043)$ or area under the curve $(r=-0.079)$. In addition, no relationship existed between the mean fasting values for the 19 individual meals and the mean peak rise $(r=-0.131)$ or area $(r=-0.078)$.

\section{Legume Comparisons}

Of the 35 paired comparisons between a bean and another food, ten involved groups of three, 12 groups of four, three groups of five, eight groups of six, one group of seven and one group of eight individuals.

The mean rise in blood glucose concentrations for the beans by comparison with the seven other starchy 


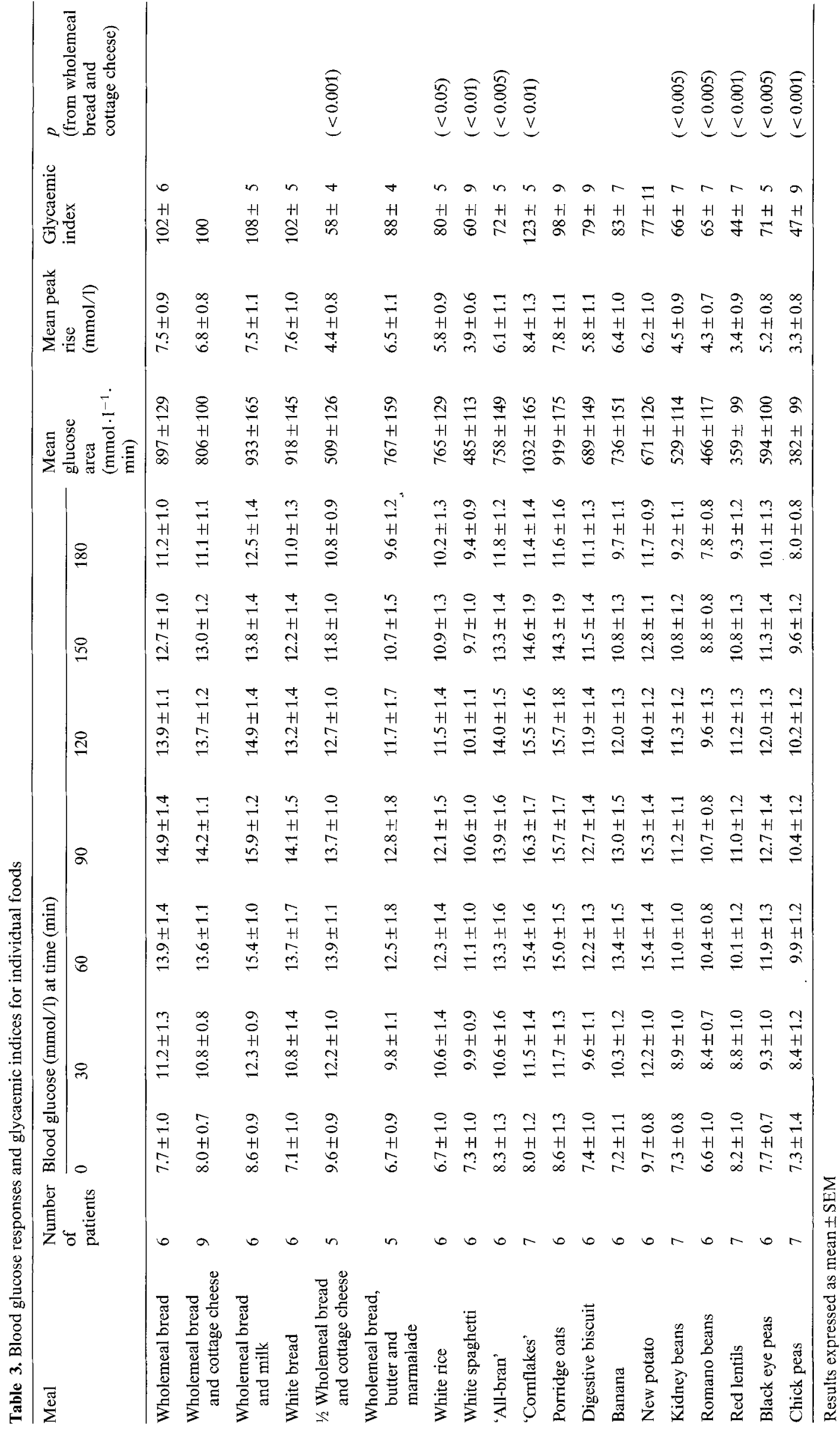


Table 4. Paired comparisons between legumes and the other foods taken by diabetic patients

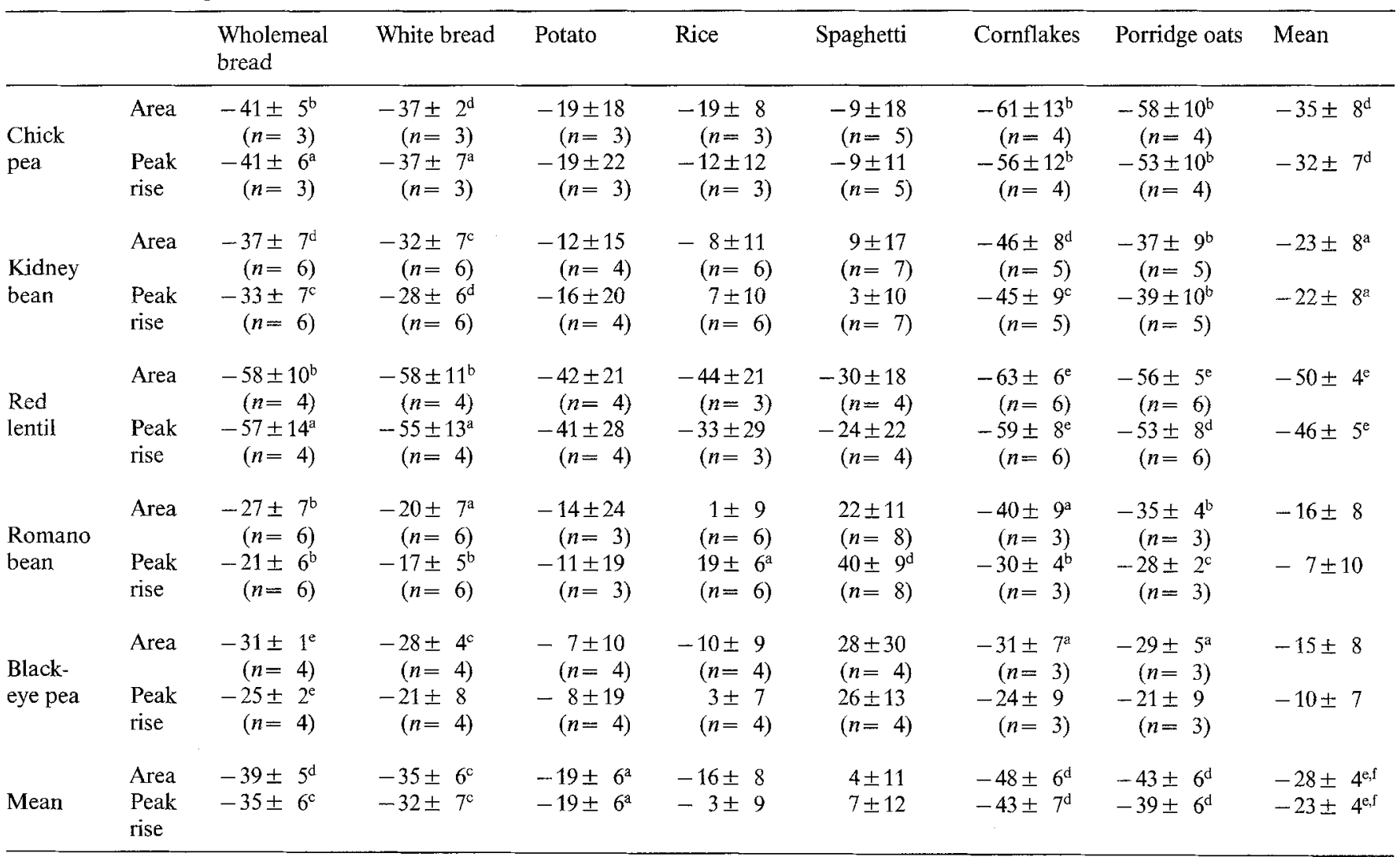

Results expressed as the mean \pm SEM of percentage differences in peak rises and areas under the blood glucose response curve.

${ }^{\mathrm{a}}=p<0.05 ;{ }^{\mathrm{b}}=p<0.02 ;{ }^{\mathrm{c}}=p<0.01 ;{ }^{\mathrm{d}}=p<0.005 ;{ }^{\mathrm{e}}=p<0.001 ;{ }^{\mathrm{f}}=$ Mean $\pm \mathrm{SEM}$ of all 35 comparisons

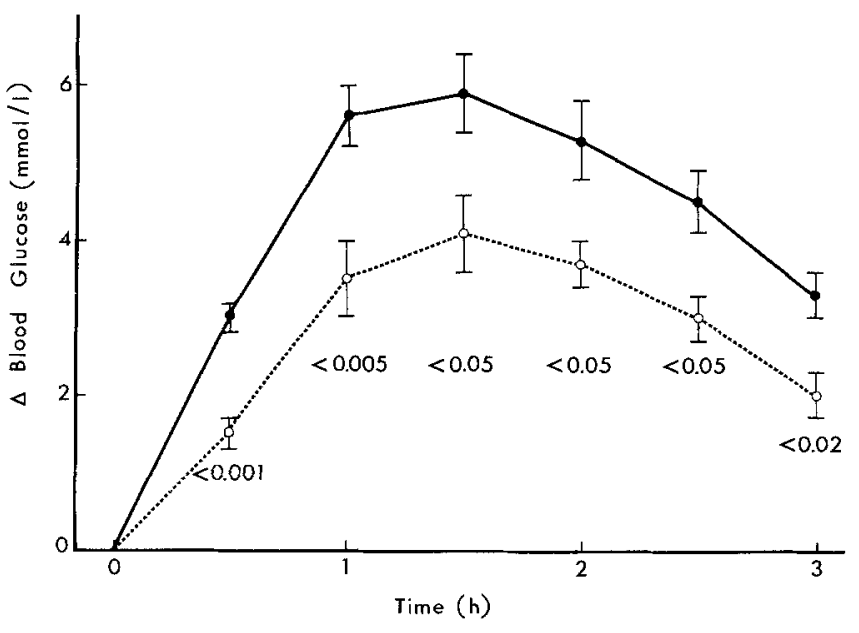

Fig. 1. Increments of blood glucose (mean \pm SEM) in diabetic patients after consumption of $50 \mathrm{~g}$ carbohydrate portions of five varieties of leguminous seeds (kidney and romano beans, black eye and chick peas and red lentils: $\mathrm{O}-\ldots-\ldots$ ) and seven other starchy foods (wholemeal and white breads, rice, spaghetti, new potatoes, 'Cornflakes' and porridge oats: - The values for breakfast cereals have been reduced to allow for the contribution of the added milk

foods are given in Figure 1. At each time except fasting, the mean value for beans was significantly below that for the other foods $(p<0.05-0.001)$.

When the direct comparisons between foods taken by the same groups of individuals were considered, the overall mean blood glucose peak rise and area under the curve in response to beans were below the mean values for the other foods by $23 \pm 4 \%(p<0.001)$ and $28 \pm 4 \%(p<0.001)$ respectively (Table 4$)$. The kidney beans, chick peas and lentils produced the lowest blood glucose responses of the beans tested, their mean glucose areas being significantly below the non-leguminous foods by $23 \pm 8 \%(p<0.05), 35 \pm 8 \%(p<0.005)$ and $50 \pm 4 \% \quad(p<0.001)$ respectively (Table 4$)$. Their peak rises were also less by $22 \pm 8 \%(p<0.05), 32 \pm 7 \%$ $(p<0.005)$ and $46 \pm 5 \%(p<0.001)$. The differences between black eye peas or pinto beans and the other foods were not consistent. On the other hand, wholemeal and white bread, potato, Cornflakes and porridge showed the highest blood glucose responses, all having significantly greater glucose areas and peak rises than the legumes (Table 3). Spaghetti and rice did not, however, show significantly different areas and peak rises from the beans.

When the blood glucose areas of the three additional individuals (subjects 10-12) were expressed as a glycaemic index based on $50 \mathrm{~g}$ carbohydrate portions of wholemeal bread, rather than wholemeal bread and cottage cheese, the values for the foods they tested (white bread $89 \pm 10 \%$, spaghetti $62 \pm 10 \%$, rice $66 \pm 3 \%$, pinto beans $70 \pm 12 \%$, kidney beans $60 \pm 15 \%$ ) were not significantly different from the original glycaemic indices based on the values of the first nine volunteers. 


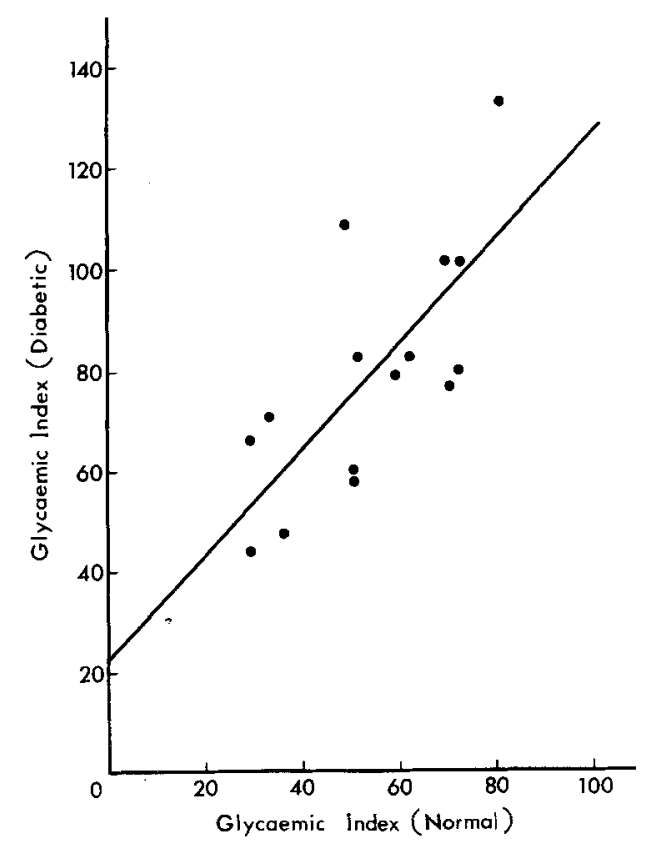

Fig. 2. The relationship between the glycaemic index of 15 foods tested in normal volunteers and the same foods tested in diabetic patients $(r=0.756, p<0.01)$

\section{Discussion}

Our results indicate that two- to threefold differences in blood glucose response may be seen when equivalent portions of carbohydrates from different foods are eaten by diabetic subjects. Awareness of such differences is of especial importance at a time when there is a move internationally to increase the dietary fibre and carbohydrate content of the diabetic diet [1-3].

The suggested carbohydrate intake by the American [1] and Canadian [2] Diabetes Associations and the British Diabetic Association [3] are now respectively: $50 \%-60 \%$ [1]; over 45\% [2] (with no upper limit); and $50 \%$ or more [3] of the caloric intake with emphasis on high fibre foods as sources of carbohydrate. One major aim has been to lower fat intake in an endeavour to reduce the possible risk to the diabetic of cardiovascular disease [22]. However, in the absence of specific details as to exactly how the carbohydrate intake was to be increased, concern was expressed after publication of the American Diabetes Association's guidelines that it might be from items which would compromise good blood glucose control [4]. In response to this the British Diabetic Association and Canadian Diabetes Association guidelines suggested the use of cereal products, certain root vegetables and legumes [2,3]. This was on the basis of studies demonstrating that the nature of starch may be an important determinant of the blood glucose and insulin responses to foods in normal and diabetic individuals $[20,23-25]$. Nevertheless, the British Diabetic Association statement acknowledged that more work was urgently needed to define the glycaemic response to different foods [3].
Although much emphasis has been placed on the need to increase the intake of dietary fibre in the diet of diabetic individuals $[1-3,5-7,9-11]$, comparatively little attention has been paid to differences which may exist between different types of fibre [26]. Certain leguminous seed fibres, eg. guar, have been shown to reduce the glycaemic response in both normal [27] and diabetic [28] volunteers. In addition, longer term studies of diabetics showed that their urinary glucose losses were reduced with guar supplementation [12-15]. However, in healthy subjects cereal fibre has been largely without effect as illustrated by similar responses to white and wholemeal bread [29]. The current study indicates that the same is also true for diabetic patients. Nevertheless, in the long term other aspects of cereal fibre, as for example in wholemeal bread, may be beneficial [30].

The Diabetes Associations [1-3] have advised against the use of added sugar and emphasis has been placed on increasing the use of 'complex' as opposed to 'simple' carbohydrates and sugars. Nevertheless, the British Diabetic Association has suggested that some sugar, for example in high fibre breakfast cereals, may have no more, or possibly less, effect on blood glucose than sugar-free low fibre foods [3]. This is borne out here by the $40 \%$ lower glycaemic responses after Allbran compared with Cornflakes, despite the fact that $36 \%$ of the carbohydrates in 'All-bran' were sugars compared with only $9 \%$ in Cornflakes. Similarly the sugars in the banana, digestive biscuits, and bread and marmalade meals did not lead to high glycaemic responses. One explanation for this is the relatively flat blood glucose rise seen after sucrose or fructose as reported in normal subjects [31], the value being respectively only 60 and $20 \%$ that of glucose [20]. However, for reasons other than the acute effect on the glycaemic response (eg. the effect on serum triglyceride [32]) it may be advisable to limit both sugar and refined carbohydrate intake.

Addition of $12.1 \mathrm{~g}$ protein to the meal (an increase of $121 \%$ ) in the form of cottage cheese made no difference to the bread glycaemic response. This is despite its suggested role in increasing insulin secretion [33] and so lowering the post-meal blood glucose response when taken as part of a mixed meal.

Conversely a change in food form, with no major difference in the ratio of starch to protein (white bread 6.4, spaghetti 6.2), resulted in the large disparity in glycaemic response between white bread and spaghetti. Recently a similar difference has been reported in normal volunteers [29]. The factors involved in this alteration in food form are unknown but may relate to the very "hard" wheat (Triticum durum) used in making spaghetti. Nevertheless, these differences could not be predicted from food tables based on chemical analysis. However particle size has been implicated in studies of whole or ground rice [34] and whole or puréed apples [33].

The comparisons of beans with other foods indicate 
that the beneficial effects seen when leguminous seeds have been included in diets for diabetics $[5,10,11]$ may be explained by the flatter blood glucose responses they produce.

Much of the original interest in beans was stimulated by the use of the bean fibre, guar, in the treatment of diabetes [12-15]. However, many factors in addition to fibre may be responsible for the effects of the whole bean. Recently comparison of a range of carbohydrate foods [37] and foods processed in different ways [38] have indicated that the glycaemic response may be predicted from the rate at which a food is digested in vitro. In turn the digestibility of foods has been shown to be reduced by the presence of enzyme inhibitors [39], lectins [40] and phytates [41], all of which are contained in beans. In vitro studies of cooked legumes have indeed shown that these are digested less rapidly than other carbohydrate foods $[37,42]$.

Carbohydrate malabsorption resulting from slow digestion may also contribute to the lower blood glucose levels seen after feeding low glycaemic index foods. Assessed by breath hydrogen evolution, substantial carbohydrate malabsorption has been reported after consumption of legumes [43]. However, our own results using this method suggested that, for example, after eating lentils only $13 \%$ of the carbohydrate was malabsorbed by comparison with $6 \%$ after wholemeal bread [44]. This small difference in carbohydrate malabsorption did not account for the $72 \%$ difference in the blood glucose responses between the two meals [44].

Previous studies of normal volunteers have demonstrated low post-prandial blood glucose rises after consumption of a range of beans [36]. The flattest responses were seen after consumption of lentils and kidney beans. The picture was therefore similar to that seen here in the diabetic patients.

In addition to their effect in long-term diabetic studies, a further possible use for dried legumes and perhaps other low glycaemic index foods has recently been reported. It was shown that addition to the diet of as little as $30 \mathrm{~g}$ dried beans per day over a $1-3$ month period reduced the serum cholesterol level of hypercholesterolaemic individuals [45].

There is therefore a growing body of evidence to suggest that high fibre starchy foods such as legumes could usefully be incorporated into the diabetic diet.

For the practical purpose of diet formulation, the number of foods tested here was relatively small. We have, however, tested a much larger series including over 60 foods and sugars studied in normal volunteers [20]. In that series the glycaemic index was derived using glucose as the standard, rather than bread, as used here for the diabetic patients.

Comparison of the results in the normal and diabetic volunteers indicated that the glycaemic indices of the 15 foods common to each series were significantly related $(r=0.756, n=15, p<0.01$; Fig. 2$)$. The mean area under the $3 \mathrm{~h}$ blood glucose curve for the 15 foods tested in diabetic subjects was $681 \pm 54 \mathrm{mmol} \cdot \mathrm{l}^{-1} \cdot \mathrm{min}^{-1}$ which was almost five times that of the same foods tested over $2 \mathrm{~h}$ in normal subjects $\left(119 \pm 11 \mathrm{mmol} \cdot 1^{-1} \cdot \mathrm{min}^{-1}\right.$ [36]. A relationship very similar to that for glycaemic index was also seen when the absolute blood glucose areas for diabetic and non-diabetic volunteers were compared ( $r=0.753 n=15, p<0.01$ ).

Such a finding was of interest since the items tested in the normal series were obtained in Oxford and London, UK, while those used for the diabetic subjects were bought in Toronto, Canada. The similar pattern of glycaemic responses in normal and diabetic subjects is of particular importance in view of the criticism which can be levelled at any study where values are derived from food tables rather than directly from food analysis. These results may therefore extend the range of foods on which potentially useful physiological data are available for formulating diabetic diets.

The relative benefits of high carbohydrate diets selected specifically on the basis of glycaemic index as opposed to fibre or sugar content remain to be evaluated clinically. Nevertheless, where low glycaemic diets have been chosen for other reasons the results show great promise [5-7, 9-11].

Acknowledgements. We thank Mrs. V. Bishop, Mr. H.Cowan, Mrs. S. Davidson, Mr. L. Desrochers, Mrs. E. Hipper, Miss I. Lawson, Mr. R. Sora, Mr. H.Stumff, Mr. W. Thornton, Mr. W.Lewis, Mrs. A. Montanaro and Mrs. K. Matsumoto whose enthusiastic collaboration made these studies possible. We are also grateful to Sister Elaine and Staff Nurse Mrs. M. Ross for their help. The Canadian Diabetes Association and Natural Sciences and Engineering Research Council supported this study through grants to DJAJ.

\section{References}

1. Nuttall FQ (1979) Dietary recommendations for individuals with diabetes mellitus: Summary of report from the Food and Nutrition Committee of the American Diabetes Association. Am J Clin Nutr 33: 1311-1312

2. Special Report Committee of the Canadian Diabetes Association (1981) 1980 Guidelines for the nutritional management of diabetes mellitus: A special report from the Canadian Diabetes Association. J Can Dietet Assoc 42: 110-118

3. The Nutrition Sub-Committee of the British Diabetic Association's Medical Advisory Committee: Dietary recommendations for diabetics for the 1980's. Final Draft July 1981

4. Reaven GM (1980) How much carbohydrate? Diabetologia 19: 409-413

5. Anderson JW, Ward K (1979) Longterm effects of high-carbohydrate high-fiber diets on glucose and lipid metabolism: A preliminary report on patients with diabetes. Diabetes Care 1: 77-82

6. Anderson JW, Midgley WR, Wedman B (1979) Fiber and diabetes. Diabetes Care 2:329-389

7. Simpson RW, Mann JI, Eaton J, Moore RA, Carter R, Hockaday TDR (1979) Improved glucose control in maturity-onset diabetes treated with high-carbohydrate-modified fat diet. $\mathrm{Br}$ Med $\mathrm{J} 1$ : $1753-1756$

8. Jenkins DJA, Wolever TMS, Bacon S, Nineham R, Lees R, Rowden R, Love M, Hockaday TDR (1980) Diabetic diets: high carbohydrate combined with high fiber. Am J Clin Nutr 33: 1729-1733

9. Anderson JW, Ward K (1979) High-carbohydrate, high-fiber diets for insulin treated men with diabetes mellitus. Am J Clin Nutr 32: $2312-2321$ 
10. Simpson HCR, Lousley S, Geekie M, Simpson RW, Carter RD, Hockaday TDR, Mann JE (1981) A high carbohydrate leguminous fibre diet improves all aspects of diabetic control. Lancet 1: $1-5$

11. Rivellese A, Giacco A, Genovese S, Riccardi G, Pacioni D, Mattioli PL, Mancini M (1980) Effect of dietary fibre on glucose control and serum lipoproteins in diabetic patients. Lancet 1: 447-449

12. Jenkins DJA, Wolever TMS, Hockaday TDR, Leeds AR, Haworth R, Bacon S, Apling EC, Dilawari J (1977) Treatment of diabetes with guar gum. Lancet 2: 779-780

13. Jenkins DJA, Wolever TMS, Nineham R, Taylor R, Metz GL, Bacon S, Hockaday TDR (1978) Guar crispbread in the diabetic diet. Br Med J 2: 1744-1746

14. Jenkins DJA, Wolever TMS, Taylor RH, Reynolds D, Nineham R, Hockaday TDR (1980) Diabetic glucose control, lipids, and trace elements on long-term guar. Br Med J 280: 1353-1354

15. Aro A, Uusitupa M, Vontilainen E, Hersio K, Korhonen T, Siitonen O (1981) Improved diabetic control and hypocholesterolaemic effect induced by long-term dietary supplementation with guar gum in Type 2 (insulin-independent) diabetes. Diabetologia 21: 29-33

16. Diem K, Lentner C (eds) (1972) Documenta Geigy: Scientific Tables. JR Geigy SA, Basle, p712

17. Paul AA, Southgate DAT (1978) McCance and Widdowson's The composition of foods, 4th edn. (Medical Research Council Special Report Series No.297). Her Majesty's Stationery Office, London

18. Platt BS (1977) Tables of representative values of foods commonly used in tropical countries. MRC Special Report Series No.302, Her Majesty's Stationery Office, London

19. Adams CF (1975) Nutritive value of American foods. Agriculture Handbook No.456, United States Department of Agriculture, US Government Printing Office, Washington

20. Jenkins DJA, Wolever TMS, Taylor RH, Barker $H$, Fielden $H$, Baldwin JM, Bowling AC, Newman HC, Jenkins AL, Goff DV (1981) Glycemic index of foods: A physiological basis for carbohydrate exchange. Am J Clin Nutr 34:362-366

21. Clark LC Jr (1973) A polarographic enzyme electrode for the measurement of oxidase substrates. In: Kessler M, Bruley DF, Leland CC, Lubbers DW, Silver IA, Strass J (eds) Oxygen supply. Urban \& Schwarzenberg, Munich, pp 120-128

22. Jarrett RJ (1981) How much carbohydrate? Diabetologia 20: 507 (Letter)

23. Jenkins DJA, Wolever TMS, Taylor RH, Barker HM, Fielden $H$ (1980) Exceptionally low blood glucose response to dried beans: Comparison with other carbohydrate foods. $\mathrm{Br}$ Med $\mathrm{J} 281$ : $578-580$

24. Crapo PA, Reaven G, Olefsky J (1977) Postprandial plasma-glucose and -insulin responses to different complex carbohydrates. Diabetes 26: $1178-1183$

25. Crapo PA, Kolterman OG, Waldeck N, Reaven AM, Olefsky JM (1980) Postprandial hormonal responses to different types of complex carbohydrate in individuals with impared glucose tolerance. Am J Clin Nutr 33: 1723-1728

26. Jenkins DJA (1979) Dietary fibre, diabetes and hyperlipidaemia. Lancet 2: 1287-1290

27. Jenkins DJA, Leeds AR, Gassull MA, Cochet B, Alberti KGMM (1977) Decrease in postprandial insulin and glucose concentrations by guar and pectin. Ann Intern Med 86: 20-23

28. Jenkins DJA, Leeds AR, Gassull MA, Wolever TMS, Goff DV, Alberti KGMM, Hockaday TDR (1976) Unabsorbable carbohydrates and diabetes: Decreased post-prandial hyperglycaemia. Lancet 2: 172-174
29. Jenkins DJA, Wolever TMS, Taylor RH, Barker HM, Fielden H, Gassull MA (1981) Lack of effect of refining on the glycemic response to cereals. Diabetes Care 4: 509-513

30. Bosello O, Ostuzzi R, Armellini F, Micciolo RM, Ludovico AS (1980) Glucose tolerance and blood lipids in bran-fed patients with impaired glucose tolerance. Diabetes Care 3: 46-49

31. Macdonald I, Keyser A, Pacy D (1978) Some effects, in man, of varying the load of glucose, sucrose, fructose, or sorbitol on various metabolites in blood. Am J Clin Nutr 31: 1305-1311

32. Mann JI, Truswell AS (1972) Effects of isocaloric exchange of dietary sucrose and starch on fasting serum lipids, postprandial insulin secretion and alimentary lipaemia in human subjects. Br J Nutr 27: 395-405

33. Fajans SS, Floyd JC, Knopf RF, Conn JW (1967) Effect of amino acids and proteins on insulin secretion in man. Rec Prog Horm Res 23:617-656

34. O'Dea K, Nestel PJ, Antonoff L (1980) Physical factors influencing postprandial glucose and insulin responses to starch. Am $\mathbf{J}$ Clin Nutr 33: 760-765

35. Haber AB, Heaton KW, Murphy D (1977) Depletion and disruption of dietary fibre: effects on satiety, plasma-glucose, and serum insulin. Lancet 2: 679-682

36. Jenkins DJA, Wolever TMS, Taylor RH, Barker $H$, Fielden $H$ (1980) Exceptionally low blood glucose response to dried beans: comparison with other carbohydrate foods. Br Med J 2: 578-580

37. Jenkins DJA, Ghafari H, Wolever TMS, Taylor RH, Barker HM, Fielden H, Jenkins AL, Bowling AC (1982) Relationship between the rate of digestion of foods and post-prandial glycaemia. Diabetologia 22: $450-455$

38. O'Dea K, Snow P, Nestel P (1981) Rate of starch hydrolysis in vitro as a predictor of metabolic responses to complex carbohym drate in vivo. Am J Clin Nutr 34: 1991-1993

39. Puls W, Keup V (1973) Influence of an $\alpha$-glucoside inhibitor (Bay d7791) on blood glucose, serum insulin and NEFA in starch loading tests in rats, dogs and man. Diabetologia 9:97-101

40. Puzstai A, Clarke EMW, King TP (1979) The nutritional toxicity of Phaseolus vularis lectins. Proc Nutr Soc 38: 115-120

41. Cheryan M (1980) Phytic acid interactions in food systems. CRC critical reviews. I Foods Science and Nutrition 13: 297-310

42. Jenkins DJA, Wolever TMS, Taylor RH, Ghafari $H$, Jenkins AL, Barker H, Jenkins MJA (1980) Rate of digestion of foods and postprandial glycaemia in normal and diabetic subjects. Br Med 2: 14-17

43. Murphy EL, Calloway DH (1972) The effect of antibiotic drugs on the volume and composition of intestinal gas from beans. Digestive Diseases 17: 639-642

44. Jenkins DJA, Wolever TMS, Taylor RH, Griffiths C, Krzeminska K, Lawrie JA, Bennett CM, Goff DV, Sarson DL, Bloom SR (1982) Slow release carbohydrate improves second meal tolerance. Am J Clin Nutr 35: 1339-1346

45. Bingwen L, Zhaofeng W, Wanzhen L, Rongjue Z (1981) Effects of bean meal on serum cholesterol and triglycerides. Chinese Med J 94: $455-458$

Received: 13 May 1982

and in revised form: 2 December 1982

Dr. D. J.A. Jenkins

Department of Nutritional Sciences

Faculty of Medicine

Toronto University

Toronto, Canada M5S 1A8 